\title{
TRANSLATING BLACK FEMINISM: THE CASE OF THE EAST AND WEST GERMAN VERSIONS OF BUCHI EMECHETA'S THE JOYS OF MOTHERHOOD
}

\begin{abstract}
Feminism in Translation Studies has received a considerable amount of attention in the West, most especially in Canada from where it emanated. Also, studies in translation and Black Feminism have been carried out by scholars such as Silva-Reis and Araujo (2018) and Amissine (2015). There has, however been few studies focusing on the translation of literary texts by African feminist writers into German. This study therefore examined how Womanism in Buchi Emecheta's The Joys of Motherhood was transferred into German. Against this backdrop, the two translations published during the division of Germany into two states by different political ideologies were analyzed. In doing this, Postcolonial Theory of translation as conceived by Spivak (2004) was employed. The study aimed at determining how translation mechanisms have influenced the manner in which black feminist activism is represented in a distinct socio-cultural environment. This is with the focus to indicate how Womanism is represented differently in the two German translations of the African novel.
\end{abstract}

Keywords: Feminism. Womanism. Translation. Ideology. East and West Germany.

\section{RESUMO}

Os estudos sobre feminismo em tradução têm recebido considerável atenção no Ocidente, especialmente no Canadá, de onde ele se irradiou. De igual modo, estudos sobre tradução e feminismo negro têm sido empreendidos por pesquisadores como Silva-Reis e Sousa de Araujo (2015) e Amissine (2015). Há, no entanto, poucos estudos centrados na tradução de textos literários de autoras feministas africanas em alemão. Este artigo portanto examina como o mulherismo de The Joys of Motherhood, de Buchi Emecheta, foi translado para o alemão. Contra esse pano de fundo, analisaramse as duas traduções publicadas, sob diferentes ideologias políticas, durante a divisão da Alemanha em dois Estados. Visou-se determinar de que modo os mecanismos de tradução influenciaram a maneira como o ativismo feminista negro é representado num ambiente sociocultural específico. O objetivo é mostrar como o mulherismo está representado de maneiras diferentes nas duas traduções alemãs deste romance africano.

Palavras-chave: feminismo, mulherismo, tradução, ideologia, Alemanha ocidental e oriental.

Omotayo I. Fakayode

Department of Linguistics and Language Practice. University of Free State, Bloemfontein, South Africa. Email: omotayo2004@gmail.com 


\section{Introduction}

One of the most popular Nigerian female writers, Buchi Emecheta, who lives in Britain empathizes with women in her works and is highly "respected for her imaginative and documentary writing about African women's experiences" (Olawoyin 2017). She has been described as one of the most important female authors to emerge from postcolonial Africa and is distinguished for her vivid description of female subordination and conflicting cultural values in modern Africa (Sougou 2002). In addition, Emecheta is "highly regarded for introducing an authentic female perspective to contemporary African literature" (Essay 2018). In her novels, she engages the injustice of traditional male-oriented African social customs that relegate women to a life of child-bearing, servitude and victimization. Due to her preoccupation with feminine issues, amongst others women/girls as protagonists, motherhood and marriage (an important cultural tradition for African women), Emecheta has been classified as a feminist writer. However, in an essay on contemporary literary criticism, it was noted that:

Emecheta differentiates her own Afrocentric perspective from that of her Western counterparts by describing herself as 'an African feminist with a small f' (Essay 2018).

Whatever she opines with her own type of feminism with the small "f" could probably be deduced from her writings. This could be based on the fact that she still recognizes African culture and traditions in her works. She eulogizes the female character and is preoccupied with the injustice and inequalities girls and women suffer in the African society. She sees marriage as perpetuating a woman's powerlessness and motherhood compounding her disability. This in a way aligns with the notion of Western feminism but departs from the radical feminism of Western culture.

Emecheta has published several works and the most published of them is The Joys of Motherhood. This work portrays a tale of a conventional African lady Nnu Ego - a personality who knows her character and its completion in having numerous kids particularly the male. In spite of poverty, she defines herself as rich for she has three sons. In terms of Ibuza tradition, she thought she would experience an agreeable seniority because of the assistance of her children. Having described Nnu Ego's excruciating life in Lagos, a colonized city, the novel concludes with her shocking death. A desolate passing on without a child to hold her hand and no companion to converse with her. She had never truly made numerous companions as she was occupied with delights of motherhood. Describing the novel, Marie Umeh states:

In Buchi Emecheta's novel, The Joys of Motherhood, one witnesses the collapse of these glorifying images of the African mother. As a literary artist preoccupied with promoting change, 
author Emecheta, an iconoclast, breaks away from the prevalent portraitures in African writing in which motherhood is honorific... The title of the book, which is taken from Flora Nwapa's novel, Efuru is then significant and bitterly ironic... Here Emecheta constructs a completely different set of economic socio-political and cultural imperatives which diverge from the existing literary models. (Umeh 1982: 40)

From the above, it can be deduced that although the title of the novel seems to romanticize motherhood, the theme of the novel contradicts the essence of the title. The title of the novel is appealing, especially to an African feminist, since it encapsulates motherhood and "appears to be part of the significant body of feminist literature concerned with women's experience of motherhood in patriarchal cultures" (Maclean 2003: 1). The irony of the title, The Joys of Motherhood does not however imply that the feminist writer, Emecheta, jettisons the need to be a mother in the African society. She, as a matter of fact, does not align herself to the notions of radical feminism, but rather to the need for African women to reject traditional stereotypes and to opt for a radical change of their situation in society. In view of the above, the following section reviews the relevant concept of black feminism, namely Womanism.

\section{Womanism and Emecheta's The Joys of Motherhood}

African feminist theorists, observing that Western feminism excludes the experience of the black woman informed the development of black feminist theories, such as Stiwanism, motherism and womanism, which account for black women's experiences. In the 1980s, Chikwenye Okonjo Ogunyemi and the African-American Alice Walker proposed the first version of African feminism, namely Womanism. The philosophy of Womanism differed from Western feminism as it appeals to unity rather than separateness. Furthermore, it celebrates the ideals of black life and incorporates racial, cultural, national, economic and political considerations in the plight to defend women. According to Ogunyemi (1988), Womanism is

Black centred; ... unlike radical feminism, it wants meaningful union between black women and black men and black children and will see to it that men begin to change from their sexist stand (Ogunyemi 1988 cited in: Alkali et al. 2013: 240).

Womanism is a reasoning that praises African roots, the beliefs of African life, while giving a clear presentation of the African woman liberation. Its ultimate aim is black solidarity where each African individual has some form of power (Adesanmi 2004 cited in: Alkali 2013: 241). 
The womanist consciousness cannot be excluded from Emecheta's The Joys of Motherhood in view of the fact that the author conceives her own type of feminism to be Womanism (Barfi \& Alaei 2015: 12). The author's womanist position can be investigated through Ogunyemi's womanist theory, which extends beyond sexism to incorporate national, political, social and economic considerations. According to Collins Amartey (2013: 76), this is a project to demand an holistic change in the lives of African women.

In view of this, Emecheta's novel could be considered as a womanist novel by scrutinizing the title and chapter titles. Although the titles eulogize the feminine personality, they include references to the male counterpart and children as well. Chapters 2, 3 and 18, for example, focus on the mother (women): The Mother's Mother, The Mother's Early Life and A Canonised Mother. As a womanist, the author includes men and children in her chapter titles. Chapters 13, 16 and 17 refer to children, $A$ Good Daughter, A Mother of Clever Children and A Daughter's Honour, while chapters 6, 7 and 12 includes the role of men, A Man is Never Ugly, The Duty of a Father and Men at War.

Apart from the social aspect stated above, the national, political and economic aspects visible in the chapter titles of the womanist novel are The Rich and the Poor (chapter 8), A Mother's Investment (chapter 9), Men at War (chapter 12) and The Soldier Father (chapter 15). From the foregoing, since black feminism has been evident through the title of the novel and its chapter titles it is pertinent to examine the role different ideologies play in their transfer into German. In order to achieve this, there is the need to consider the different ideologies of the former East and West Germany, which led to the publication of two different German translations of Emecheta's The Joys of Motherhood.

\section{Ideology in the former East and West Germany}

For years, Germany was dominated by different political and economic systems and two worldviews with different ideologies emerged, namely liberal democracy or capitalism in West Germany and socialist democracy or communism in East Germany. The difference between these ideologies lies in the fact that West Germany favored the ideology of liberalism or private property, which lead to a philosophical, economic and political current that aspired individual freedom or individualism as a normative basis of the social and economic order. East Germany saw the development of an ideology of socialism, which referred to a communist model of private property. The aim of the East Germany ideology was to change the existing social relations to ensure social equality and justice, as well as a social order organized according to these principles. During this period of division, relations between the two German states were reserved and sometimes hostile. A socialist dictatorship was put into place in East Germany, the press was censored and the economy was owned and 
controlled by the state. In East Germany, the state also controlled the publishing of literary works and the translation of novels from other languages into German. The state owned two publishing houses, Verlag Neues Leben and Verlag Volk und Welt, which were to publish translations of African literature. As such, the translation of literary works in West Germany was not permitted in the East.

The hegemony the two German states imposed on African literature resulted in the production of different German translations of many African literary works, particularly those by Ngugi wa Thiong'o and Chinua Achebe. Emecheta's The Joys of Motherhood is the only Anglophone feminist novel, which was translated in both East and West Germany (Kolb 2010: 282). The East German translation was published by Verlag Neues Leben, while the West German translation was published by a publishing house for women writers, namely Frauenbuchverlag.

The following analysis considers the way in which the different ideologies, capitalism, liberalism, individualism, socialism and communism crystalized in the two German translations of the novel. Against this backdrop, it would be exigent to gain insight into how the different ideologies affected the lives of women in the two German states which existed at that time and how this issue influenced the representation of black feminism in the German translations of Emecheta's The Joys of Motherhood.

\section{Women's Lifestyles in the former East and West Germany}

According to Haug (2018), socialist feminism insists that in the modern world, the oppression of women is inextricably linked to the history of capitalism and that feminist demands for change must therefore address the structural links between patriarchy and capitalism. In East Germany where socialism existed, Marxist terms were adopted and corollary to this, women were encouraged to reproduce. Women in the German Democratic Republic (GDR) were also actively involved in the work force. There were kindergartens and crèches to take care of their children and their husbands typically took part in the house chores.

In contrast to this, women in Federal Republic of Germany (FRG) were typically housewives. They looked after children and did the house chores while their husbands went to work and therefore, were the breadwinners. This is a major point of critique of the mode of production of capitalism, which involves women's oppression in the form of the acquisition of unpaid labour and the use of women in gender-typical division of labour needs. In view of this, there were more laws in the GDR that favoured reproduction rights for women than in the FRG. One of this was the "Muttipolitik" (Myra 1992). On the other hand, the FRG was far less generous in its social policy for working mothers than the GDR. FRG laws were equally based on gender-specific requirements and the availability of the mother after lengthy school hours and so forth. These laws were less based on the compatibility of professional life 
activities and motherhood. It was required that the mother be available throughout the day to offer unpaid work for the maintenance of her family. Having considered the effect of political ideologies on the lives of women in both states, it is pertinent to highlight the relevant theory in analyzing the German translations of Emecheta's feminist novel considered in this study. The choice of this theory is informed by the objective of this article. This is not to compare how ideological differences resulted into two translations but to examine how different versions influenced by ideologies have represented black feminism in translation.

\section{Spivak's Postcolonial Theory of Translation}

Munday (2010) opines that the central intersection of Translation Studies and Postcolonial theory is that of power relations. Postcolonial theory aims to account for the ideological consequences of the translation of "Third World" literature into European languages and the distortion it entails. Spivak (2004), for example, spoke out against Western feminists who expect feminist writings from outside Europe to be translated into the language of power, English. According to Munday (2010), such translation in Spivak's view, is often expressed in "translatese", which eliminates the identity of the politically less powerful individuals and cultures. Postcolonial Translation Theory, linking colonization and translation, "is accompanied by the argument that translation has played an active role in the colonization process and in disseminating an ideologically motivated image of colonized peoples" (ibid: 132). Spivak goes further to describe a kind of "politics of translation" whereby translation gives prominence to "hegemonic" languages (of ex-colonizers). In this vein, she admonishes Western feminism by saying that feminists from hegemonic countries should show real solidarity with women in postcolonial contexts by learning the language in which those women speak and write.

The assertion of Spivak on Postcolonial theory and her critique of feminism in the postcolonial context is vital to this study. Her idea of politics of translation is used to evaluate to what extent German translators have been able to assimilate African feminism in the target texts. In the following, an analysis of the two German translations of the selected novel shall be carried out.

\section{The East and West German Translations of Emecheta's The Joys of Motherhood}

In this section, I first analyze the respective translations of the novel's title and thereafter the analysis of the translations of the chapter titles in the book. 


\section{The Title(s)}

It is worthy to note that the author emphasizes a crucial aspect of Igbo culture through the title of the novel. Marriage is very important in the lives of Igbo women, so also is motherhood (Akujobi 2011). In fact, motherhood crowns a woman's marriage in Igbo culture and it is symbolic to the essence of marriage. Therefore, the author depicts this cultural belief as "Joys" and thus, "Joys of Motherhood".

The GDR translator transferred the title into German as closely as possible. Even though the word "motherhood" was translated as "Mutter" and not "Mutterschaft" in this translation, the source text author's concept of "Motherhood" is still communicated to a large extent. The GDR version of the title reads Die Freuden einer Mutter.

On the other hand, the individualistic nature, which is corollary to liberalism in a capitalist society can be deduced from the West German translation of the title as Nnu Ego. Zwanzig Säcke Muschelgeld (Nnu Ego. Twenty Bags of Cowries). In this title, the translators emphasize the heroine of the novel, Nnu Ego. This is individualistic and not part of the intention of the author. The translators also further state the meaning of the name Nnu Ego as "Zwanzig Säcke Muschelgeld" [Twenty bags of cowries]. Being a capitalist society interested in economic profits, the meaning of the heroine's name is quite important for the West German translators. More specifically, they attempt to present the theme of the novel as only focused on the individual and in so doing emphasize her economic value. Thus, the communal life of an African woman in relation to her family, husband and children, is overlooked. Besides, reframing the title in this case underestimates African feminism, which emphasizes motherhood as a joyous experience.

\section{The Chapter Titles}

The novel has 18 chapters, of which seven refer to "the mother", six focus on men, two on girls, one on children and two on economy. Of the 18 chapters, the East and West translators translated nine of them the same way and nine of them differently. Ideological undertones can however be deduced from the different translations. In the similar translations, the translators maintained a close equivalent to the source text, for example:

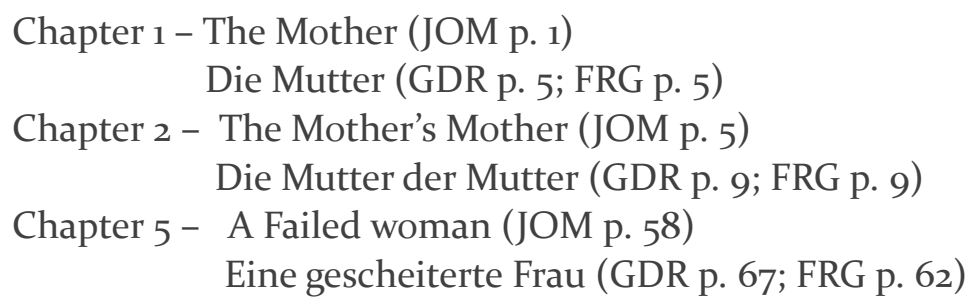




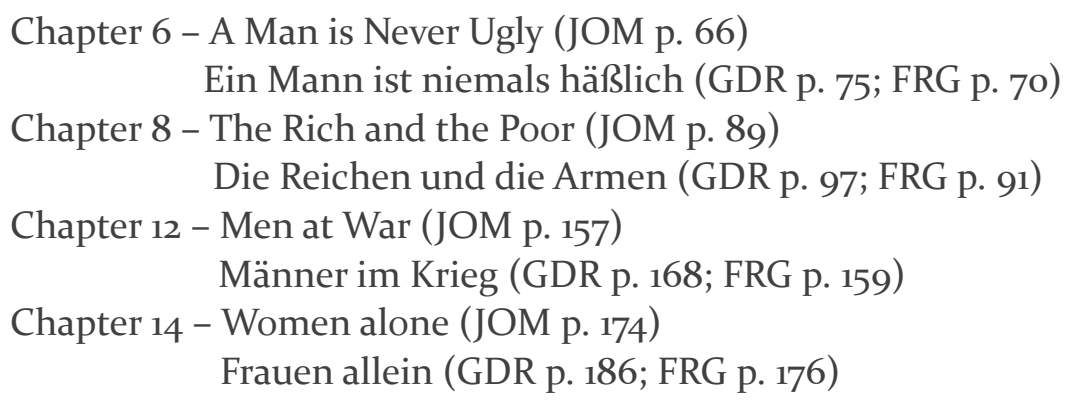

It is worthy to note that the two translators translated some chapter titles not exactly, probably due to differences between English and German. For example:

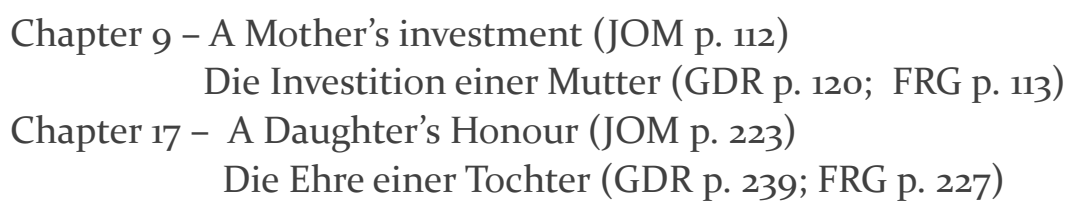

There are however two examples of such a case from which ideological undertones could be inferred. In these cases, an indefinite article was replaced by a definite one. The ideological implication of the replacement of an indefinite with a definite article can be understood in the context of communality versus individualism. The use of "a/an" could be communal referring to anyone while "the" is more particular. The communal or socialist ideology versus liberal or individualistic one can be deduced from the differences between the East and West translations of the following titles:

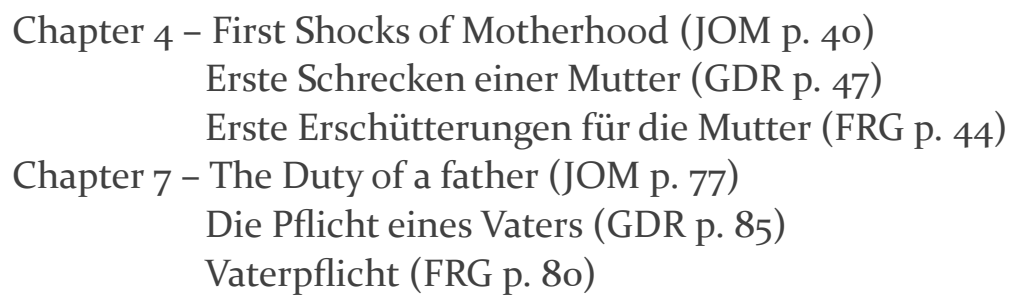

Chapter 18 which is titled "A Canonised Mother" (JOM p. 239) is translated as "Die heiliggesprochene Mutter" in GDR (p. 256) translation. This is a more general view of women and also more communal than the FRG version, namely "Die Mutter wird heiliggesprochen" [The mother is canonized] (p. 244). The FRG version is more individualistic focusing on the exaltation of a personality.

Also in chapter 15, "The Soldier Father" (JOM p. 190), the GDR version reads "Vater, der Soldat" [Father, the soldier] (p. 203), while the FRG version reads "Der Vater als Soldat" [The father as soldier] (p. 193). The East German translation refers to a figure who defends his country and the West German translation depicts it as being the choice of the individual. 
Furthermore, the choice of the word "Jugendzeit" [early life] in GDR's version of the title of chapter 3 inculcates a life involving others and other things, whereas FRG's translated the word as "Mädchen" [girl] focuses on the individual. The source and target texts read:

\author{
The Mother's Early Life (JOM p. 27) \\ Die Jugendzeit der Mutter (GDR p. 33) \\ Vom Mädchen zur Mutter (FRG p. 31)
}

In a few cases, there are inferences to socialist ideology in the West German translation and liberalism in the East German translation. For example, the title of chapter 11 which reads "Sharing a Husband" (JOM p. 140) is translated as "Ein Mann für zwei Frauen” [A man for two women] (p. 149) in GDR's version and as "Zwei Frauen teilen sich einen Mann" [Two women share a man] (p. 141) in FRG's translation. Despite the fact that the notion of sharing is more paramount in a social economy like that which existed in East German at the time, the East German translator completely reframed the title in a capitalist way. He omitted the word "share" whereas in contrast to this, in the West German translation, the word "share" (teilen) is emphasized as the translator chose to be more explicit than the author herself.

A similar scenario played out in chapter 16 where the East German translator omitted the indefinite article in his translation, making the translation more individualistic. The West German translators translated as close as possible to the original and by doing so (adding "eine"), the idea presented in the title is less specific. The title of the chapter and its translations read:

\author{
A Mother of Clever Children (JOM p. 211) \\ Mutter von tüchtigen Kindern (GDR p.226) \\ Eine Mutter von klugen Kindern (FRG p. 215)
}

\title{
Conclusion
}

From the foregoing, it has been shown that there are considerable differences between the East and West German translations of Emecheta's The Joys of Motherhood title and chapter titles, which have resulted in variations in the representation of Black African Feminism to the target reader. It has also been discussed that the author's own feminism, which is Womanism, is different from the radical feminism from the West. In line with Postcolonial Theory, which describes how Western ideologies tend to colour translations from third world countries, Spivak criticizes the Western feminist and postulates the need to show solidarity with women in postcolonial contexts by learning what is theirs and representing it accordingly. The 
solidarity advocated by Spivak can be minimally inferred from the analysis of the East and West German translations of the title and chapter titles of Emecheta's The Joys of Motherhood carried out above.

Nonetheless the different ideologies of the then East and West German states, which conditioned the situation of women in the respective areas have serious implications for the translation of black feminism as indicated in the target texts used for the study. For instance, the situation of women in FRG looked more like that of the African woman because in both cases, women stayed at home to care for their children and to take responsibility of house chores, while the man was the breadwinner. However, the individualism and capitalist system in FRG is projected in the translation and it is at variance with the kind of black feminism presented in the source text. The kind of feminism in the source text is more communal, involving the society - men and children - and this makes the socialist system, the communal life which operated in East Germany and is evident in the GDR translation more appropriate in representing black feminism i.e. the experience of the black woman.

\section{References}

ADESANMI, Pius. (2004): "Of Postcolonial Entanglement and Duree: Reflections on the Francophone Novel". Comparative Literature, n. 3, 56: p. 228-242.

AKUJOBI, Remi. (2011). "Motherhood in African Literature and Culture". Comparative Literature and Culture, n. 1, 12: p. 1-7.

ALKALI, Muhammad; TALIF, Rosli. YAHYA, Wan Roselezam Wan \& JAN, Jariah Mohd. (2013). "Dwelling or Duelling in Possibilities: How (Ir)relevant are African Feminisms?" GEMA Online Journal of Language Studies, n. 3, 13: p. 237-253.

AMARTEY, Collins. (2013). "Articulations of Womanism in Adichie's Purple Hibiscus and Emecheta's The Joys of Motherhood. Thesis (Masters in English) - University of Ghana.

AMISSINE, Itang. (2015). "Feminism And Translation: A Case Study of Two Translations of Mariama Ba: Une Si Longue Lettre (So Long A Letter) and Un Chant ecarlate (Scarlet Song)". Mini-Dissertation (Masters in Applied Language Studies) - University of Pretoria.

BARFI, Zahra \& ALAEI, Sarieh. (2015). "Western Feminist Consciousness in Buchi Emecheta's The Joys of Motherhood”. International Letters of Social and Humanistic Sciences, n. 1, 1: p. 12-20. 
BUCHI. Emecheta. (2018). Contemporary Literary Criticism. Available at: <http:// www.enotes.com/topics/buchi-emecheta/critical-essays/emecheta-buchi>. Accessed on: 8 December 2018.

EMECHETA, Buchi. (1983). Die Freuden einer Mutter. Translated by Rainer Ronsch. Berlin: Verlag Neues Leben.

EMECHETA, Buchi. (1983). Nnu Ego. Zwanzig Sacke Muschelgeld. Translated by Helmi Martini-Honus and Jurgen Martini. Munchen: Frauenbuchverlag.

EMECHETA, Buchi. (1979, 2008). The Joys of Motherhood. Edinburgh: Heinemann.

FAKAYODE, Omotayo. (2018). "Die Analyse von Intertextualiät in den deutschen Übersetzungen von Ngugis Petals of Blood und Achebes No Longer At Ease". Thesis (Doctorate in German Language and Linguistics) - Obafemi Awolowo University, IleIfe, Unpublished.

FEREE, Myra Marx. (1992). "Aufstieg und Untergang der "Muttipolitik": Feminismus und deutsche Vereinigung". Diskurs 2, n. 1, p. 6o-65.

HAUG, Frigga. (2018). Sozialistischer Feminismus: Eine Verbindung im Streit. Available at: <http://www.friggahaug.inkrit.de/documents/haug-sozialistischerFeminismus. pdg>. Accessed on: 8 December 2018.

KOLB, Waltraud. (2010). "Noch nicht unter zu vielen Geschichten begraben": Englischsprachige Literatur aus Afrika auf dem deutschen Buchmarkt". In: BACHLEITNER, Norbert \& WOLF, Michaela. (eds). Streifzüge in translatorischen Feld. Zur Soziologie der literarischen Übersetzung im deutschsprachigen Raum. Berlin: LIT Verlag. p. 278-292.

MACLEAN, Patricia. (2003). How Buchi Emecheta's The Joys of Motherhood Resists Feminist and Nationalist Readings. Deep South. Available at: <http://www.otago. ac.nz/deepsouth/2003_o1/motherhood.html>. Accessed on: 8 December 2018

MUNDAY, Jeremy. (2010). Introducing Translation Studies: Theories and Applications. London/New York: Routledge.

OGUNYEMI, Chikwenye. (1988). "Woman and Nigerian Literature". In: YEMI, Ogunbiyi (ed.). Perspectives on Nigerian Literature. Lagos: Guardian Books. p. 6o-67. 
OLAWOYIN, Oladeinde. (2017). "Tributes Pour in for Late Novelist, Buchi Emecheta”. Premium Times Online Newspaper. Available at: <http://www.premiumtimesng. com/entertainment/artsbooks/221837-tributes-pour-late-novelist-buchi-emecheta. html>. Accessed on: 8 December 2018.

SOUGOU, Omar. (2002). Writing Across Cultures: Gender Politics and Difference in the Fiction of Buchi Emecheta. New York: Rodopi.

SILVA-REIS, D.; ARAÚJO, C. G. S. (2018). “Translation Studies And Black Diaspora Studies: A Brazilian Itinerary”. In: REVISTA DA ANPOLL (ONLINE). v. 44, p. 83-99.

SPIVAK, Gayatri. (1993/2004) “The Politics of Translation”. In: VENUTI, Lawrence (ed.). The Translation Studies Reader. London/New York: Routledge. p. 369-388.

UMEH, Marie. (1982). “The Joys of Motherhood: Myth or Reality?” Colby Quaterly, n. 1, 18: p. 39-46. 